\title{
Sarcopenia and sarcopenic obesity: do they predict inferior oncologic outcomes after gastrointestinal cancer surgery?
}

\author{
Kimberly L. Mei', John A. Batsis ${ }^{2,3,4}$, Jeannine B. Mills² and Stefan D. Holubar ${ }^{2,3^{*}}$
}

\begin{abstract}
Sarcopenia, or loss of skeletal muscle mass and quality, has been studied as part of aging and adverse health outcomes in elderly patients but has only recently been evaluated as a separate condition in cancer patients and important indicator of adverse outcomes. Currently, its definition and method of assessment are still being debated. Sarcopenia within an increasingly obese population has led to a subgroup with sarcopenic obesity, at even higher risk of adverse outcomes. Yet, sarcopenia often goes undiagnosed in these patients, hidden beneath higher body mass index. Identifying sarcopenic and sarcopenic obese subpopulations would allow for more effective treatment plans and potential avoidance of suboptimal outcomes, as well as the chance to intervene and combat these modifiable risk factors. This review will examine available literature on the definition and methods of evaluating sarcopenia and sarcopenic obesity, summarize the effectiveness of sarcopenia and sarcopenic obesity as predictors of outcomes after gastrointestinal cancer surgery, including colorectal cancer resection, liver resection, and pancreatic resection, and outline strategies to minimize the impact of sarcopenia. It is clear that untreated sarcopenia and sarcopenic obesity can be associated with suboptimal post-operative outcomes, especially infections and disease-free or overall survival.
\end{abstract}

Keywords: Body composition, Obesity, Oncologic, Sarcopenia, Surgery, Surgical oncology, Colorectal cancer, Pancreatic cancer, Hepatectomy, Malnutrition

\section{Background}

Sarcopenia, the loss of skeletal muscle mass and quality that occurs as part of natural aging, can be exacerbated by systemic illnesses. Within the last 10 years, this geriatric syndrome has received increasing attention as a possible predictor of adverse outcomes after surgery (Lentine et al. 2011; Mueller et al. 2015). Traditional oncological therapies and perioperative nutritional assessments that focus on weight loss and markers such as serum albumin have overlooked sarcopenia as a determinant of prognosis after oncological surgery. Presently, there is no practical, objective, or easily accessible measure of individual frailty, a general concept that encompasses age-related decline across physiologic systems as well as in psychological and social well-being, resulting

\footnotetext{
* Correspondence: Stefan.Holubar@dartmouth.edu

${ }^{2}$ Dartmouth-Hitchcock Medical Center, Lebanon, NH, USA

${ }^{3}$ Geisel School of Medicine at Dartmouth, Hanover, NH, USA

Full list of author information is available at the end of the article
}

in impaired homeostatic reserve (Clegg et al. 2013; Bauer and Sieber 2008; Singh et al. 2014). Sarcopenia, considered a more reproducible signal of frailty, often precedes its development and could more effectively identify patients at higher risk of suboptimal benefit from systemic chemotherapy and surgery (Peng et al. 2011; van Vledder et al. 2012; Buettner et al. 2016).

With the increased prevalence of obesity, those with both sarcopenia and obesity (sarcopenic obesity (SO)) are at higher risk of adverse outcomes, including disability (Baumgartner et al. 2004) and mortality (Batsis et al. 2014a). These associations have not been well investigated in relation to many cancer surgeries. Sarcopenia is often underdiagnosed (Fielding et al. 2011; Prado et al. 2008), as it is not always easily characterized from overall weight loss alone or decreased body mass index (BMI), especially in obese patients (Batsis et al. 2014b). Establishing standard criteria is critical to accurately evaluate and make use of its prognostic abilities. 
In this review, we aim to summarize recent literature regarding the impact and effectiveness of sarcopenia and $\mathrm{SO}$ as predictors of gastrointestinal (GI) oncologic surgery outcomes, including colorectal cancer resection, liver resection, and pancreatic resection, and promising methods by which these risk factors can be modified.

\section{Defining sarcopenia, cancer cachexia, and SO}

Early definitions of sarcopenia rely upon measures of muscle mass and neglect a functional specification. Evidence suggests the relationship between low muscle mass and adverse outcomes is not linear or direct; rather, they are linked when low muscle mass is associated with muscle weakness (Cruz-Jentoft et al. 2010; Studenski et al. 2014). Recent definitions have evolved to additionally include measures of muscle performance or strength (Table 1).

In 2010, the European Working Group on Sarcopenia in Older People established a working clinical definition of sarcopenia as the presence of both abnormally low muscle mass and low muscle function, either physical performance or strength, in the form of low gait speed or low handgrip strength (Cruz-Jentoft et al. 2010).

In 2014, the Foundation for the National Institutes of Health alternatively defined sarcopenia as a "differential diagnosis" reached through sequential screening for poor physical function, muscle weakness, and low muscle mass. Low gait speed manifested poor physical performance, and inability to rise from a chair (without using arms) or time required to complete five chair stands were also useful standards. Muscle strength was assessed through unadjusted grip strength and muscle mass via body mass-adjusted appendicular lean mass (Studenski et al. 2014).

Sarcopenia is further distinguished from general cancer-related cachexia, "a multifactorial syndrome characterized by an ongoing loss of skeletal muscle mass (with or without loss of fat mass) that cannot be fully reversed by conventional nutritional support and leads to progressive functional impairment," which encompasses varying levels of body fat and muscle loss (Dodson et al. 2011; Fearon et al. 2006; Fearon et al. 2011; Fouladiun et al. 2005). Sarcopenia specifically denotes muscle loss (Peng et al. 2012). While cancer cachexic patients experience weight loss and diminished BMI, sarcopenic patients can have normal or increased BMI. As a result, it is still important to screen cancer surgery patients for sarcopenia (Fearon et al. 2011).

During aging and malignancy, lean body mass is lost while fat mass remains constant or increases, possibly leading to SO. SO is defined by subjects who fulfill the combination of criteria for sarcopenia and a given measure of adiposity, such as BMI, waist circumference (WC), computerized tomography (CT)-derived total body fat (TBF), or dual x-ray energy absorptiometry (DXA)/bioelectric impedance analysis (BIA)-derived body fat (Batsis et al. 2013; Lieffers et al. 2012) (Table 1). Metrics of adiposity more precise than BMI, which fluctuates with changes in both muscle and adiposity, may predict cancer outcomes more accurately. Traditional BMI cutoffs have poor diagnostic accuracy when identifying obesity, especially in older populations (Batsis et al. 2016; Romero-Corral et al. 2008).

Previously, decreases in muscle mass were considered largely responsible for muscle weakness and mobility impairment in patients with $\mathrm{SO}$, but current research suggests that deterioration of muscle quality (evidenced by phenomena such as "marbling" or fat infiltration into muscle) is an overlooked contributor (Cruz-Jentoft et al. 2010). Both aging and obesity are associated with decline in muscle quality and higher rates of fat infiltration (Zamboni et al. 2008). Studies find that although obese elderly subjects often acquire a higher absolute muscle mass than non-obese frail and normal counterparts to compensate for body habitus (Visser et al. 2002), they have the poorest muscle quality and strength and, like the non-obese frail, exhibit reduced functional status, aerobic capacity, strength, balance, and gait speed (Villareal et al. 2004). This suggests that sarcopenia and SO may be seriously underdiagnosed, since previous definitions largely ignore muscle quality and the retrospective nature of many existing studies investigating sarcopenia and cancer surgery limits them to criteria relying on muscle mass. Moreover, there remains variability within cutoffs used across studies and uncertainty regarding the applicability of these criteria to all ethnic groups (Studenski et al. 2014).

\section{Diagnosing sarcopenia and SO}

Various morphometric measures are used to quantify muscle mass (Table 1), including appendicular skeletal muscle (ASM) index (the sum of lean soft-tissue masses for the arms and legs adjusted by height) (Fig. 1) (Baumgartner et al. 1998) and those of core muscles such as total skeletal muscle cross-sectional area at the level of the third lumbar vertebrae (L3mi) (Prado et al. 2008), total psoas area (TPA) (Peng et al. 2011), and psoas density (PD) (Sabel et al. 2011).

Muscle mass has traditionally been measured using BIA or DXA (Chien et al. 2008), but presently, CT and magnetic resonance imaging (MRI) are considered the gold standard methods of assessing body composition in research (Cruz-Jentoft et al. 2010; Bonekamp et al. 2008; Malafarina et al. 2012). CT and MRI are not routinely used in clinical practice for sarcopenia assessment or adiposity assessment, due to concerns about radiation and high cost (Cruz-Jentoft et al. 2010). DXA is inexpensive, most precise for measuring appendicular muscle 
Table 1 Definitions and cutoffs for sarcopenia and sarcopenic obesity assessment

\begin{tabular}{|c|c|c|c|c|c|c|c|c|c|}
\hline Sarcopenia definition & Study & $\begin{array}{l}\text { Functional component } \\
\text { of definition }\end{array}$ & $\begin{array}{l}\text { Body composition } \\
\text { analysis method }\end{array}$ & $\begin{array}{l}\text { Muscle mass } \\
\text { definition }\end{array}$ & Pros & Cons & $\begin{array}{l}\text { Obesity } \\
\text { definition }\end{array}$ & Pros & Cons \\
\hline $\begin{array}{l}\text { ASM index }>2 \text { SDs } \\
\text { below sex-specific } \\
\text { means of Rosetta study } \\
\text { reference data } \\
\text { (Gallagher et al. 1997) }\end{array}$ & $\begin{array}{l}\text { Baumgartner } \\
\text { (Baumgartner } \\
\text { et al. 1998) }\end{array}$ & - & DXA & $\begin{array}{l}\text { ASM } / \mathrm{m}^{2} \\
\text { (Heymsfield } \\
\text { et al. 1990) }\end{array}$ & - & $\begin{array}{l}\text { No functional } \\
\text { component }\end{array}$ & $\%$ body fat & $\begin{array}{l}\text { Measures have been } \\
\text { experimentally validated } \\
\text { in comparison with BMl } \\
\text { (Gallagher et al. 2000) } \\
\text { Highly correlated with } \\
\text { estimates from DXA } \\
\text { (Baumgartner et al. 1998) }\end{array}$ & - \\
\hline $\begin{array}{l}\text { Low gait speed or } \\
\text { low handgrip } \\
\text { strength with } \\
\text { low muscle mass }\end{array}$ & $\begin{array}{l}\text { Cruz-Jentoft } \\
\text { (Cruz-Jentoft } \\
\text { et al. 2010) }\end{array}$ & $\begin{array}{l}\text { Gait speed } \leq 0.8 \mathrm{~m} / \mathrm{s} \\
\text { or }>0.8 \mathrm{~m} / \mathrm{s} \text { with } \\
\text { handgrip strength } \\
\text { below sex-specific } \\
\text { cutoffs }\end{array}$ & - & - & $\begin{array}{l}\text { Contains functional } \\
\text { component, capturing } \\
\text { more of sarcopenia due } \\
\text { to poor muscle quality/ } \\
\text { fat infiltration }\end{array}$ & - & - & - & - \\
\hline $\begin{array}{l}\text { Low gait speed or } \\
\text { inability to rise from } \\
\text { chair with low } \\
\text { handgrip strength } \\
\text { and body mass- } \\
\text { adjusted ASM below } \\
\text { sex-specific cutoffs }\end{array}$ & $\begin{array}{l}\text { Studenski } \\
\text { (Studenski } \\
\text { et al. 2014) }\end{array}$ & $\begin{array}{l}\text { Gait speed } \leq 0.8 \mathrm{~m} / \mathrm{s} \\
\text { or inability to rise from } \\
\text { a chair with handgrip } \\
\text { strength below sex- } \\
\text { specific cutoffs (men } \\
<26 \mathrm{~kg} \text {, women }<16 \mathrm{~kg} \text { ) }\end{array}$ & DXA & ASM/BMI & $\begin{array}{l}\text { Contains functional } \\
\text { component, capturing } \\
\text { more of sarcopenia due } \\
\text { to poor muscle quality/ } \\
\text { fat infiltration } \\
\text { Recommendations } \\
\text { based on the largest, } \\
\text { most diverse samples } \\
\text { to have been studied }\end{array}$ & - & BMl & $\begin{array}{l}\text { Most common and widely } \\
\text { available measure, easy to } \\
\text { evaluate }\end{array}$ & $\begin{array}{l}\text { Inaccurate, } \\
\text { fluctuates } \\
\text { with } \\
\text { changes } \\
\text { in both } \\
\text { muscle } \\
\text { and fat }\end{array}$ \\
\hline \multirow{7}{*}{$\begin{array}{l}\text { L3mi below sex- } \\
\text { specific cutoffs } \\
\text { associated with } \\
\text { mortality in cohort } \\
\text { obtained through } \\
\text { optimum stratification }\end{array}$} & $\begin{array}{l}\text { Prado (Prado } \\
\text { et al. 2008), } \\
\text { Lieffers (Lieffers } \\
\text { et al. 2012) }\end{array}$ & - & \multirow{7}{*}{$\begin{array}{l}\text { Secondary } \\
\text { analysis of CT } \\
\text { images } \\
\text { (Mitsiopoulos } \\
\text { et al. 1998; } \\
\text { Shen et al. 2004) }\end{array}$} & \multirow[t]{7}{*}{ L3mi } & - & \multirow[t]{7}{*}{$\begin{array}{l}\text { No functional } \\
\text { component }\end{array}$} & BMl & \multirow[t]{4}{*}{-} & \multirow[t]{4}{*}{-} \\
\hline & $\begin{array}{l}\text { Dello (Dello } \\
\text { et al. 2013) }\end{array}$ & & & & & & & & \\
\hline & $\begin{array}{l}\text { Voron (Voron } \\
\text { et al. 2015) }\end{array}$ & & & & & & & & \\
\hline & $\begin{array}{l}\text { Levolger } \\
\text { (Levolger } \\
\text { et al. 2015) }\end{array}$ & & & & & & & & \\
\hline & $\begin{array}{l}\text { van Vledder } \\
\text { (van Vledder } \\
\text { et al. 2012) }\end{array}$ & & & & & & $\begin{array}{l}\text { Intra-abdominal } \\
\text { fat (Yoshizumi } \\
\text { et al. 1999) }\end{array}$ & $\begin{array}{l}\text { Significantly associated with } \\
\text { disease-free survival in men } \\
\text { undergoing resection of } \\
\text { colorectal liver metastases } \\
\text { (van Vledder et al. 2012) }\end{array}$ & - \\
\hline & $\begin{array}{l}\text { Harimoto } \\
\text { (Harimoto } \\
\text { et al. 2013) }\end{array}$ & & & & & & - & - & - \\
\hline & $\begin{array}{l}\text { Lodewick } \\
\text { (Lodewick } \\
\text { et al. 2015) }\end{array}$ & & & & & & $\%$ body fat & - & - \\
\hline
\end{tabular}


Table 1 Definitions and cutoffs for sarcopenia and sarcopenic obesity assessment (Continued)

\begin{tabular}{|c|c|c|c|c|c|c|c|c|c|}
\hline $\begin{array}{l}\text { L3mi in the lowest } \\
\text { sex-specific quartile }\end{array}$ & $\begin{array}{l}\text { Miyamoto } \\
\text { (Miyamoto } \\
\text { et al. 2015) }\end{array}$ & - & $\begin{array}{l}\text { Secondary analysis } \\
\text { of } C T \text { images }\end{array}$ & L3mi & - & $\begin{array}{l}\text { No functional } \\
\text { component }\end{array}$ & - & - & - \\
\hline $\begin{array}{l}\text { No specific cutoffs } \\
\text { established (lower } \\
\text { density reflects more } \\
\text { frailty) }\end{array}$ & $\begin{array}{l}\text { Sabel (Sabel } \\
\text { et al. 2013) }\end{array}$ & - & $\begin{array}{l}\text { Secondary analysis } \\
\text { of } C T \text { images }\end{array}$ & PD & $\begin{array}{l}\text { A measure of muscle } \\
\text { quality or fat infiltration }\end{array}$ & $\begin{array}{l}\text { No functional } \\
\text { component }\end{array}$ & $\begin{array}{l}\text { VF, SFD, } \\
\text { TBF, or } \\
\text { BMI }\end{array}$ & $\begin{array}{l}\text { VF: risk factor for } \\
\text { developing colorectal } \\
\text { cancer and significantly } \\
\text { associated with increased } \\
\text { tumor recurrence in } \\
\text { colorectal cancer patients } \\
\text { (Moon et al. 2008) } \\
\text { SFD: significant predictor of } \\
\text { wound infection following } \\
\text { colectomy for colon cancer } \\
\text { (Sabel et al. 2013) } \\
\text { TBF: significant predictor } \\
\text { of outcome following } \\
\text { colectomy for colon } \\
\text { cancer (Sabel et al. 2013) }\end{array}$ & - \\
\hline $\begin{array}{l}\text { TPA } / \mathrm{m}^{2} \text { equal to or } \\
\text { below cutoff obtained } \\
\text { through optimum } \\
\text { stratification }\end{array}$ & $\begin{array}{l}\text { Peng (Peng } \\
\text { et al. 2011) }\end{array}$ & - & $\begin{array}{l}\text { Secondary analysis } \\
\text { of } C T \text { images }\end{array}$ & $\mathrm{TPA} / \mathrm{m}^{2}$ & - & $\begin{array}{l}\text { No functional } \\
\text { component }\end{array}$ & BMl & - & - \\
\hline \multirow[t]{3}{*}{$\begin{array}{l}\mathrm{TPA} / \mathrm{m}^{2} \text { in the lowest } \\
\text { sex-specific quartile }\end{array}$} & $\begin{array}{l}\text { Peng (Peng } \\
\text { et al. 2012) }\end{array}$ & - & $\begin{array}{l}\text { Secondary analysis } \\
\text { of } C T \text { images }\end{array}$ & $\mathrm{TPA} / \mathrm{m}^{2}$ & - & $\begin{array}{l}\text { No functional } \\
\text { component }\end{array}$ & BMI & - & - \\
\hline & $\begin{array}{l}\text { Amini (Amini } \\
\text { et al. 2015) }\end{array}$ & & & & & & & & \\
\hline & $\begin{array}{l}\text { Joglekar } \\
\text { (Joglekar } \\
\text { et al. 2015) }\end{array}$ & & & & & & & & \\
\hline $\begin{array}{l}\mathrm{TPV} / \mathrm{m}^{2} \text { in the lowest } \\
\text { sex-specific quartile }\end{array}$ & $\begin{array}{l}\text { Amini (Amini } \\
\text { et al. 2015) }\end{array}$ & - & $\begin{array}{l}\text { Secondary analysis } \\
\text { of } C T \text { image }\end{array}$ & $\mathrm{TPV} / \mathrm{m}^{2}$ & $\begin{array}{l}\text { Volumetric measure } \\
\text { rather than cross-sectional } \\
\text { assessment and which } \\
\text { may be more accurate at } \\
\text { assessing a larger sample } \\
\text { of muscle mass }\end{array}$ & $\begin{array}{l}\text { No functional } \\
\text { component }\end{array}$ & BMl & - & - \\
\hline $\begin{array}{l}\text { HUAC in the lowest } \\
\text { sex-specific quartile }\end{array}$ & $\begin{array}{l}\text { Joglekar } \\
\text { (Joglekar } \\
\text { et al. 2015) }\end{array}$ & - & $\begin{array}{l}\text { Secondary analysis } \\
\text { of CT image }\end{array}$ & HUAC & $\begin{array}{l}\text { A measure of muscle } \\
\text { quality or fat infiltration }\end{array}$ & $\begin{array}{l}\text { No functional } \\
\text { component }\end{array}$ & BMI & - & - \\
\hline
\end{tabular}

To determine ASM, the sum of lean soft-tissue masses for the arms and legs is computed from CT scans and adjusted by height. To determine L3mi, two consecutive CT images are taken from the L3 to the iliac crest, and cross-sectional areas of the sum of all the muscles in these regions are computed and adjusted by body surface area. To determine PD, CT scans of the left and right psoas muscles at the level of the fourth lumbar
vertebrae are used. To determine TPA, measure the cross-sectional area of the right and left psoas muscles from CT images at the level of L3 where both vertebral spinae are clearly visible. To determine TPV, take three
manual measurements at the level of L3 on the first slice where both iliac crests were visible to assess a total of $55 \mathrm{~cm}$ total psoas length and normalize for height. To determine HUAC, compute (right Hounsfield unit calculation + left Hounsfield unit calculation)/2, where the right Hounsfield unit calculation = (right Hounsfield unit*right psoas area)/(total psoas area) and left Hounsfield unit calculation $=$ (left Hounsfield unit*left psoas area)/(total psoas area) from evaluation of both the right and left psoas at the L3 level

ASM appendicular skeletal muscle, SD standard deviation, L3mi L3 skeletal muscle index, or total skeletal muscle cross-sectional area at the level of the third lumbar vertebrae normalized for stature, Intra-abdominal fat total cross-sectional area of visceral adipose tissue, TPA total psoas muscle area, measured at the level of the L3, TPV total psoas volume, measured at the level of the L3, HUAC Hounsfield unit average calculation,

measure of radiation attenuation or muscle density and fatty infiltration, measured at the level of the $L 3, P D$ psoas density or muscle attenuation (average radiodensity), measured at the cross-sectional areas of the left and right psoas muscles at the level of the L4, VF visceral fat, visceral anterior-to-posterior distance, or the average distance between the anterior aspect of the vertebra and the linea alba, SFD subcutaneous fat distance, or

the average distance between the linea alba and the anterior skin along T-12 to L4, TBF total body fat or total AP distance, the sum of the SFD and VF 


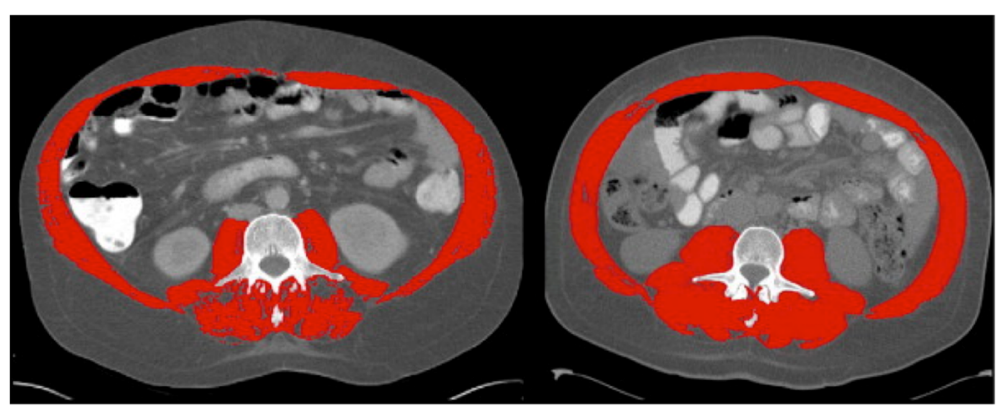

Fig. 1 Comparison of sarcopenic and non-sarcopenic computed tomography images at the third lumbar vertebral level. A comparison of two cirrhotic patients with identical BMI $\left(32 \mathrm{~kg} / \mathrm{m}^{2}\right)$. Red color indicates skeletal muscle: rectus abdominis, oblique and lateral abdominal muscles, psoas, and paraspinal muscles. The patient on the left is sarcopenic with L3mi of $49.82 \mathrm{~cm}^{2} / \mathrm{m}^{2}$; the patient on the right is not sarcopenic with L3mi of $70.8 \mathrm{~cm}^{2} / \mathrm{m}^{2}$. In their study of 112 cirrhotic patients, Montano-Loza et al. used abdominal CT images taken at the third lumbar vertebrae and cutoffs provided by Baumgartner et al. in 1998

mass, and exposes patients to minimal radiation but is not portable nor widely available for sarcopenia assessment or adiposity assessment (Bauer and Sieber 2008; CruzJentoft et al. 2010). BIA is an inexpensive, readily reproducible, portable alternative, but results are easily confounded by a number of factors, especially fluid status, and is not preferred for adiposity assessment (Bauer and Sieber 2008).

New image analysis software packages can be used with CT or MRI to streamline segmentation and obtain more consistent body composition measures for sarcopenia assessment. Semi-automated processes like SliceOmatic, NIHImageJ, Analyze, and EasyVision have yielded similar results in terms of reproducibility, while only HippoFat, a fully automated program, has shown to be slightly inferior (Bonekamp et al. 2008). While SliceOmatic segments fastest, NIHImageJ and HippoFat are free. Overall, these software packages have comparable results in analyzing MRI (Bonekamp et al. 2008) and CT images (Irving et al. 2007) but have yet to be incorporated into routine clinical practice.

\section{Functional implications of SO}

In patients $>65$, $\mathrm{SO}$ was associated with a two to three times higher chance of reporting an instrumental activities of daily living (IADL) disability than lean sarcopenic, non-sarcopenic obese, or patients with normal body composition (Baumgartner et al. 2004). While nonsarcopenic obesity and SO were both associated with lower physical activity than non-obese sarcopenic and normal body types, only SO was significantly associated with onset of IADL disability, and low physical activity was not associated with IADL disability in the absence of SO. Thus, SO is considered a worst-case scenario compounding health risks of obesity and depleted lean mass (i.e., malnutrition) (Villareal et al. 2004; Kyle et al. 2005; Roubenoff 2004; Davison et al. 2002), and cancer patients with $\mathrm{SO}$ are at higher risk of oncologic treatment-related toxicities and mortality (Tsai 2012).

\section{Impact of sarcopenia and SO on patient outcome Colorectal cancer resection}

Sarcopenia has been shown to predict complications and length of stay following colorectal surgery (Lieffers et al. 2012). Moreover, with rising levels of obesity in Western society, sarcopenia may be "hidden beneath" higher BMI.

A 2012 study of stage II-IV colorectal cancer patients undergoing primary colorectal resection found that sarcopenic patients had longer index hospitalization length of stays and post-operative length of stay, especially in those $>65$ (Table 2) (Lieffers et al. 2012). Sarcopenia was associated with increased infection risk, especially in those $>65$. Sarcopenic patients required more inpatient rehabilitation, and co-morbidities including cardiac arrhythmias, diabetes, hypertension, and deficiency anemia were more common. In patients $>65$, sarcopenia independently predicted post-operative infection and need for rehabilitation facility care but did not predict these or longer length of stay in younger patients. Though no explanation was provided, this may be because younger patients are healthier overall (more active, with fewer and less severe conditions and better physiological reserve) and exhibit smaller discrepancies in outcomes. The study provides strong evidence for sarcopenia as a predictor of short-term outcomes in colorectal cancer resection.

A 2015 retrospective study found significant associations between sarcopenia and long-term outcomes (Miyamoto et al. 2015). Sarcopenia was independently associated with higher disease recurrence, shorter recurrence-free survival, and shorter overall survival. Sarcopenia was also independently associated with shorter cancer-specific survival.

Another retrospective study on colon cancer patients undergoing colectomy obtained various morphometric measures to compare their effectiveness as predictors of post-operational outcomes to that of Charlson comorbidity index scores (Sabel et al. 2013). The single 
Table 2 Association between sarcopenia or sarcopenic obesity (SO) and oncological surgery outcomes

\begin{tabular}{|c|c|c|c|c|c|}
\hline \multirow[t]{2}{*}{ Study } & \multirow{2}{*}{$\begin{array}{l}\text { Cancer } \\
\text { type }\end{array}$} & \multicolumn{2}{|l|}{ Association with short-term oncological outcomes? } & \multicolumn{2}{|l|}{ Association with long-term oncological outcomes? } \\
\hline & & Sarcopenia & so & Sarcopenia & so \\
\hline $\begin{array}{l}\text { Prado (Prado } \\
\text { et al. 2008) }\end{array}$ & $\begin{array}{l}\text { Respiratory } \\
\text { or Gl tract }\end{array}$ & - & $\begin{array}{l}\text { Unclear, but associated with } \\
\text { poorer functional status than } \\
\text { in non-sarcopenic obese }\end{array}$ & Yes, independently predicted median survival & Yes, independently predicted survival \\
\hline $\begin{array}{l}\text { Lieffers } \\
\text { (Lieffers et } \\
\text { al. 2012) }\end{array}$ & $\begin{array}{l}\text { Colorectal } \\
\text { (stages } \\
\text { II-IV) }\end{array}$ & $\begin{array}{l}\text { Yes, independently predicted post-operative } \\
\text { infection risk, longer inpatient rehabilitation, } \\
\text { associated with higher risk of obstruction, } \\
\text { longer index hospitalization length of stay, } \\
\text { longer mean length of stay overall }\end{array}$ & - & - & - \\
\hline $\begin{array}{l}\text { Sabel (Sabel } \\
\text { et al. 2013) }\end{array}$ & Colon & $\begin{array}{l}\text { Yes, independently predicted surgical } \\
\text { complications and infectious complications, } \\
\text { associated with infectious post-operative } \\
\text { complications }\end{array}$ & $\begin{array}{l}\text { Unclear, but SFD is the best } \\
\text { predictor of post-operative } \\
\text { wound infections, and } \\
\text { associated with infectious } \\
\text { complications }\end{array}$ & $\begin{array}{l}\text { No, not an independent predictor of } \\
\text { disease-free or overall survival }\end{array}$ & $\begin{array}{l}\text { Unclear, but TBF independently } \\
\text { predicted disease-free survival }\end{array}$ \\
\hline $\begin{array}{l}\text { Miyamoto } \\
\text { (Miyamoto } \\
\text { et al. 2015) }\end{array}$ & $\begin{array}{l}\text { Colorectal } \\
\text { (stages I-III) }\end{array}$ & - & - & $\begin{array}{l}\text { Yes, independently associated with disease } \\
\text { recurrence rate, overall mortality, cancer-specific } \\
\text { mortality, recurrence-free survival, overall survival, } \\
\text { cancer-specific survival }\end{array}$ & - \\
\hline $\begin{array}{l}\text { van Vledder } \\
\text { (van Vledder } \\
\text { et al. 2012) }\end{array}$ & $\begin{array}{l}\text { Colorectal } \\
\text { liver } \\
\text { metastases }\end{array}$ & - & - & $\begin{array}{l}\text { Yes, independently predicted disease-free } \\
\text { survival and overall survival }\end{array}$ & - \\
\hline $\begin{array}{l}\text { Dello (Dello } \\
\text { et al. 2013) }\end{array}$ & $\begin{array}{l}\text { Colorectal } \\
\text { liver } \\
\text { metastases }\end{array}$ & $\begin{array}{l}\text { Yes, independently predicted disproportionally } \\
\text { small total functional liver volume }\end{array}$ & $\begin{array}{l}\text { Unclear, but fat-free body } \\
\text { mass and body surface area } \\
\text { independently predicted } \\
\text { disproportionally small total } \\
\text { function liver volume }\end{array}$ & - & - \\
\hline $\begin{array}{l}\text { Peng (Peng } \\
\text { et al. 2011) }\end{array}$ & $\begin{array}{l}\text { Colorectal } \\
\text { liver } \\
\text { metastases }\end{array}$ & $\begin{array}{l}\text { Yes, independently predicted major post- } \\
\text { operative complications, associated with risk } \\
\text { of post-operative complications, overall } \\
\text { morbidity risk, longer hospital stays, extended } \\
\text { ICU stays }\end{array}$ & $\begin{array}{l}\text { Yes, associated with major } \\
\text { post-operative complications, } \\
\text { longer hospital stays, extended } \\
\text { ICU stays }\end{array}$ & $\begin{array}{l}\text { No, not associated with recurrence-free } \\
\text { survival, overall survival or risk of recurrence }\end{array}$ & $\begin{array}{l}\text { No, not associated with overall survival } \\
\text { or recurrence-free survival }\end{array}$ \\
\hline $\begin{array}{l}\text { Lodewick } \\
\text { (Lodewick et } \\
\text { al. 2015) }\end{array}$ & $\begin{array}{l}\text { Colorectal } \\
\text { liver } \\
\text { metastases }\end{array}$ & $\begin{array}{l}\text { No, not significantly associated with risk of } \\
\text { major post-operative complications, presence } \\
\text { of liver surgery-specific composite endpoint } \\
\text { (LSSCEP) items }\end{array}$ & $\begin{array}{l}\text { No, not significantly associated } \\
\text { with risk of major post-operative } \\
\text { complications, occurrence of one } \\
\text { or more of the LSSCEP items }\end{array}$ & $\begin{array}{l}\text { No, not significantly associated with initial } \\
\text { hospital length of stay, readmission rates, } \\
\text { median disease-free survival, or overall survival }\end{array}$ & $\begin{array}{l}\text { Yes, not predictive of initial hospital } \\
\text { length of stay, disease-free survival, } \\
\text { or overall survival, but significantly } \\
\text { associated with readmission rates }\end{array}$ \\
\hline $\begin{array}{l}\text { Harimoto } \\
\text { (Harimoto et } \\
\text { al. 2013) }\end{array}$ & Liver & $\begin{array}{l}\text { Yes, independent predictor of liver } \\
\text { dysfunction }\end{array}$ & - & $\begin{array}{l}\text { Yes, independent predictor of overall and } \\
\text { recurrence-free survival }\end{array}$ & - \\
\hline \multirow[t]{2}{*}{$\begin{array}{l}\text { Voron } \\
\text { (Voron et al. } \\
\text { 2015) }\end{array}$} & Liver & $\begin{array}{l}\text { No, not associated with severe post-operative } \\
\text { complication rate, post-operative mortality or } \\
\text { morbidity rates }\end{array}$ & - & $\begin{array}{l}\text { Yes, independently associated with overall } \\
\text { and disease-free survival }\end{array}$ & - \\
\hline & Liver & $\begin{array}{l}\text { Yes, associated with major post-operative } \\
\text { complication (Clavien-Dindo grade } \geq \| l l a \text { ) and }\end{array}$ & - & $\begin{array}{l}\text { Yes, associated with overall survival, but not } \\
\text { associated with disease-free survival }\end{array}$ & $\begin{array}{l}\text { Yes, associated with shorter median } \\
\text { survival }\end{array}$ \\
\hline
\end{tabular}


Table 2 Association between sarcopenia or sarcopenic obesity (SO) and oncological surgery outcomes (Continued)

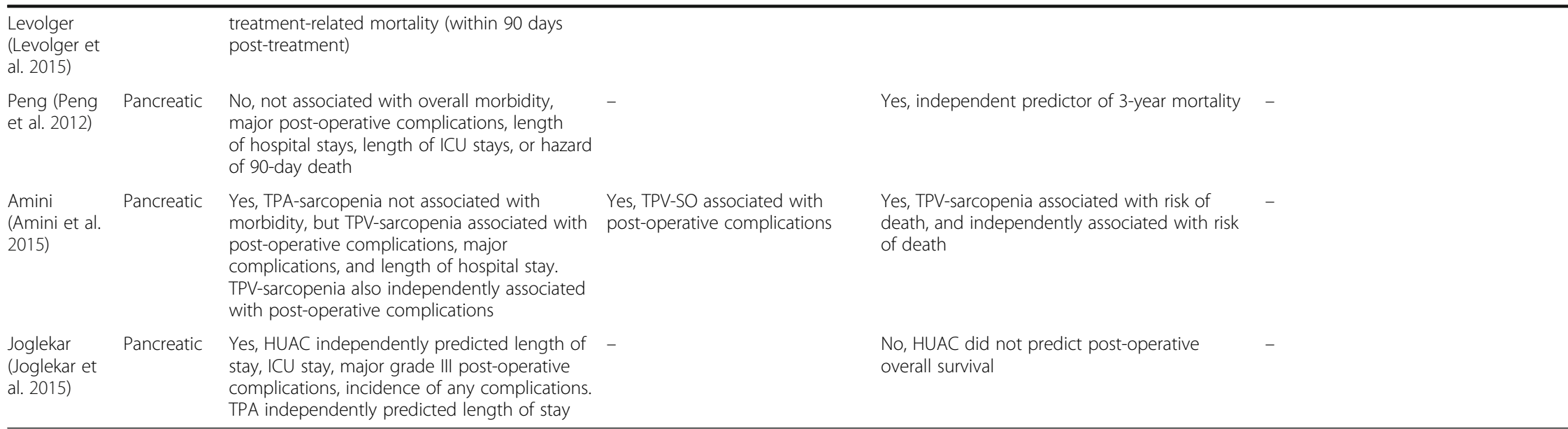

The liver surgery-specific composite endpoint (LSSCEP) is composed of ascites, post-resectional liver failure, bile leakage, intra-abdominal hemorrhage, intra-abdominal abscess, and mortality and was used to assess liver surgery-specific morbidity 
best predictor of any surgical or infectious complications was PD. When considering PD, Charlson scores, age or BMI, or specific co-morbidities were not statistically significant.

After final multivariate models controlled for age and Charlson score, PD was not significantly associated with disease-free or overall survival, but TBF was. The authors concluded that PD-sarcopenia is mainly predictive of non-colorectal cancer deaths in the population and hypothesized that frailty, or immunologic correlates, contributes less to the natural progression of colorectal cancer than it may to other cancers, such as melanoma, which an earlier study by the same authors suggested (Sabel et al. 2011).

A separate cross-sectional study found that SO in patients with solid tumors of the respiratory tract, colon, rectum, or other GI sites was significantly related to worse functional status and independently predicted survival (Prado et al. 2008).

More research is needed to clarify the most effective method of sarcopenia assessment in regard to colorectal cancer resection outcomes. Sarcopenia's effectiveness as a predictor of long-term outcomes following colorectal cancer resection is unclear, as well as the associations between $\mathrm{SO}$ and short- and long-term outcomes.

\section{Colorectal liver metastases and hepatectomy}

Sarcopenia has also been investigated in relation to liver resection. In 2012, a study on patients undergoing colorectal cancer liver metastases determined that sarcopenia was significantly associated with disproportionally small total functional liver volume (TFLV) and impaired shortterm outcomes after surgery (Dello et al. 2013). Significant correlation was also found between fat-free body mass and TFLV.

In a separate retrospective analysis, sarcopenia predicted short-term outcomes, but not long-term ones (Peng et al. 2011). Peng et al. found that sarcopenia was strongly univariately associated with increased risk of post-operative complications and overall morbidity, with sarcopenic patients $>3$ times more likely to develop a major (Clavien grade $\geq 3$ ) complication (Clavien et al. 2009). Neither TPA nor sarcopenia was predictive of recurrence-free survival, long-term overall survival, or risk of recurrence. While sarcopenic patients had longer hospital stays and higher chances of extended ICU stay (>2 days), SO patients were at even higher risk of both. In addition, $\mathrm{SO}$ was associated with an even greater risk of Clavien grade $\geq 3$ complications.

Patients with SO tended to have shorter median overall survival than other patients but, like sarcopenic patients, did not have significant differences in recurrence-free survival compared to the entire cohort. These observations support conclusions from Sabel et al. that perhaps sarcopenia has a less significant impact on the natural progression of colorectal cancer than for other cancers and thus predicts short-term outcomes following surgery in colorectal cancer, but not long-term survival.

However, in another retrospective study, sarcopenic patients had shorter median disease-free survival and lower 1-, 3-, and 5-year disease-free survival rates compared to non-sarcopenic patients (Fig. 2) (van Vledder et al. 2012). They also had decreased median overall survival and diminished 1-, 3-, and 5-year overall survival rates. Ultimately, sarcopenia independently predicted worse survival.

Most recently, however, a 2015 study found neither sarcopenia nor SO to be associated with short-term outcomes such as risk of major post-operative complications or morbidity (Lodewick et al. 2015). Moreover, sarcopenia was not significantly associated with long-term outcomes, including readmission rates or disease-free or overall survival. Interestingly, Lodewick et al. observed that sarcopenic patients had significantly higher percentage body fat and investigated $\mathrm{SO}$ in relation to outcomes. SO predicted higher readmission rates but no other long-term outcomes.

van Vledder et al.'s findings thus conflict with Peng et al.'s that sarcopenia does not predict long-term survival outcomes, and Lodewick et al. conflict with both on sarcopenia's association with short- and long-term outcomes. While multiple studies have supported an association between sarcopenia and short-term outcomes following hepatectomy of colorectal liver metastases, uncertainty remains about this association and surrounding sarcopenia's relation to long-term outcomes.

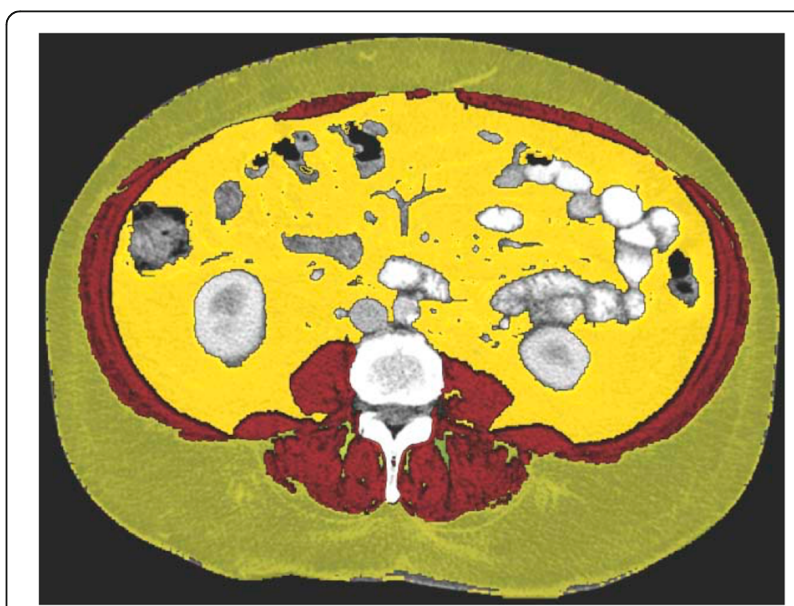

Fig. 2 Example segmented L3 computed tomography image for skeletal muscle assessment of patient undergoing hepatic resection. L3mi computed tomogram shows highlighted areas of subcutaneous (green) and intra-abdominal fat (yellow) and skeletal muscle mass (red). van Vledder et al. found a variety of body compositions within their population of 196 patients who underwent hepatic resection for colorectal liver metastases 


\section{Hepatocellular carcinoma and hepatectomy}

A 2013 retrospective study on partial hepatectomy in patients with hepatocellular carcinoma ( $\mathrm{HCC})$ noted that there is currently no objective, accessible, accurate measure of a patient's condition before undergoing hepatectomy (Harimoto et al. 2013). While the American Society of Anesthesiologists' (ASA) grading estimates functional status, it is subjective (Makary et al. 2010). Child-Pugh scores are not always reliable metrics of hepatic reserve, and Model for End-Stage Liver Disease (MELD) scores quantify mortality risk in end-stage liver disease and organ allocation processes (Teh et al. 2005). In this study, sarcopenia independently predicted overall and recurrence-free survival following surgery (Harimoto et al. 2013). As serum albumin levels were significantly lower and indocyanine green dye retention rate at $15 \mathrm{~min}$ (ICGR15) values higher in sarcopenic patients than in non-sarcopenic patients (conveying less effective hepatic removal of synthetic dye from plasma, worse hepatic functional reserve and ability to regenerate), sarcopenia was significantly associated with liver dysfunction. This study strongly supported sarcopenia as a predictor of short- and long-term outcomes following hepatectomy.

Subsequent studies disagreed. A 2015 retrospective study found that while sarcopenia was independently associated with overall and disease-free survival, it was not with short-term outcomes (Voron et al. 2015). Postoperative mortality, morbidity, and major complication rates were higher in sarcopenic than non-sarcopenic subjects but not statistically significantly so.

A separate 2015 retrospective study reaffirmed initial findings from Harimoto et al. (Levolger et al. 2015). Unlike Voron et al., Levolger et al. discovered that sarcopenia was associated with short-term outcomes such as increased risk of major post-operative complications and treatment-related mortality (death within 90 days of treatment). It was also associated with some long-term outcomes, like shorter overall survival, but not diseasefree survival.

Further research needs to evaluate the effectiveness of sarcopenia as a predictor of short-term outcomes following hepatectomy for hepatocellular carcinoma and clarify the extent to which it is a useful predictor of long-term outcomes.

Additionally, Voron et al. reported a wide range of BMI across sarcopenic subjects and emphasized the limited practicality of BMI in sarcopenia determination without CT analysis. Three subjects with identical BMI had varying L3mi values and sarcopenic status. Similarly, Levolger et al. noted the prevalence of sarcopenia in various body compositions and found that those overweight or obese and sarcopenic have significantly shorter median survival rates than non-sarcopenic obese or overweight. These findings highlight the necessity of using CT to separately screen for sarcopenia, which is convenient, as many hepatocellular carcinoma patients already undergo routine imaging (Voron et al. 2015).

\section{Pancreatic adenocarcinoma and pancreatic resection}

Recent literature has found that factors such as comorbidity, anemia, and sarcopenia may affect postoperative outcome as significantly as adjuvant oncological treatments (Fearon et al. 2013). Considerable variation in 30-day morbidity and mortality following cancer surgery and in long-term outcomes between countries supports the idea that factors outside traditional multidisciplinary team consideration may be important determinants of outcome (Baili et al. 2008; van Gijn et al. 2010).

A retrospective study on patients undergoing resection of pancreatic adenocarcinoma found that sarcopenia was an objective measure of patient frailty strongly predictive of long-term outcomes, independent of tumor-specific factors (Peng et al. 2012). Sarcopenia was not associated with short-term outcomes such as risk of overall morbidity or major complications, median ICU stays, or length of hospital stays. It was associated with increased risk of 3-year mortality. This relationship suggests that perhaps individual patient characteristics have a stronger impact on long-term outcomes of pancreatic resection than tumor-specific factors do.

However, more recent retrospective studies using volumetric or density psoas metrics found stronger associations between sarcopenia and short-term outcomes. In 2015, a retrospective study revealed stronger associations between total psoas volume (TPV)-sarcopenia and short-term outcomes than with TPA-sarcopenia (Amini et al. 2015). While TPA-sarcopenia was significantly related to risk of morbidity, TPV-sarcopenia was significantly associated with risk of any post-operative complication, risk of major complications, and length of hospital stay. Moreover, TPVsarcopenia independently predicted risk of death. TPV-SO was also associated with higher risk of post-operative complications compared to non-sarcopenic obese.

The same year, Joglekar et al. investigated the Hounsfield unit average calculation (HUAC), a measure of psoas muscle density and fatty infiltration, along with TPA (Joglekar et al. 2015). Like TPV-sarcopenia, they found that HUAC-sarcopenia was associated with more shortterm outcomes than TPA-sarcopenia. TPA-sarcopenia was associated with longer length of hospital stay, while HUAC-sarcopenia was associated with longer length of hospital stay, length of ICU stay, risk of any post-operative complication, and risk of major complications. One point of contrast between Joglekar et al. and Amini et al. was that unlike TPV-sarcopenia, HUAC-sarcopenia did not strongly predict long-term outcomes.

These findings reiterate the importance of identifying the most clinically significant assessment methods of 
sarcopenia before determining its utility as a predictor. Amini et al. determined that volumetric standards for sarcopenia like TPV might be more clinically useful as predictors of cancer surgery outcomes than cross-sectional area measures such as TPA. Similarly, a definition based on muscle density forecasted short-term outcomes better than TPA (though not long-term outcomes) (Joglekar et al. 2015).

\section{Strategies to minimize the impact of sarcopenia and SO}

While sarcopenia assessment can help identify cancer surgery patients at risk of worse outcomes, it is important to note that sarcopenia and SO themselves are modifiable. The most effective interventions to date are physical exercise and adequate nutritional protein intake (Deutz et al. 2014; Bauer et al. 2013). Pharmacological therapies for sarcopenia including inhibitors of myostatin, testosterone, selected androgen receptor modulators, ghrelin agonists, and angiotensin-converting enzyme (ACE) inhibitors have been evaluated, but preliminary trials have found that they are less effective than postulated (Molfino et al. 2016; Morley et al. 2014). In older adults vulnerable to functional decline, moderate-intensity physical activity significantly reduces risk of onset of major mobility disability compared to health education and, to a larger degree, risk of persistent mobility disability (Pahor et al. 2014). Since the primary outcome of sarcopenia is mobility disability, a proven intervention from the mobility disability literature, moderate physical activity, is a promising intervention for non-aging sarcopenic patients as well. In addition, relative sarcopenia in obese elderly was significantly ameliorated by diet regimens, exercise programs, or their combination (Villareal et al. 2011). Fat mass decreased under diet or exercise programs or their combination, but lean body mass decreased less under diet-exercise than with only diet and increased under an exercise program. A diet and exercise program yielded the greatest improvements in physical performance and the most consistent changes in strength, balance, and gait and thus may be an important therapy for $\mathrm{SO}$ subpopulations.

\section{Conclusions}

The impact of sarcopenia on post-operative oncologic outcomes and its usefulness as a predictor is still unclear and often conflicting, particularly in the case of hepatectomy for colorectal liver metastases and hepatectomy for hepatocellular carcinoma. However, sarcopenia is promising as a predictor of short-term outcomes following colorectal cancer surgery and long-term outcomes following hepatectomy for hepatocellular carcinoma. SO is promising as a predictor of long-term outcomes following hepatectomy for hepatocellular carcinoma and shortterm outcomes following pancreatic resection. The other associations need additional clarification, as studies provided inconsistent results.

There remains considerable variation in definition, cutoffs, and assessment methods for sarcopenia and SO, which makes translation to clinical practice complicated. Recent criteria incorporating both grip strength and appendicular skeletal muscle allow more clinically meaningful associations with long-term outcomes and are preferred to definitions excluding a functional component (Studenski et al. 2014; McLean et al. 2014). Though ramifications have been explored in geriatric populations, sarcopenia assessment may be more easily assimilated into clinical practice for cancer surgery patients, as routine imaging is already completed for these populations. Semiautomated segmentation software also promises to play a major role in streamlining sarcopenia assessment integration into routine practice.

Sarcopenia and SO may predict short- and long-term outcomes, and effective identification of patients at risk of poorer outcomes from cancer surgery allows for tailored interventions. As clinicians become increasingly aware of this subtle form of malnutrition, addressing sarcopenia preoperatively can optimize outcomes for at-risk patients.

\section{Future directions}

Further research is needed to reach consensus regarding the ideal manner of assessing sarcopenia in order to predict outcomes after various cancer surgeries and across cancers in a broad clinical sense. The prevalence and impact of $\mathrm{SO}$ in various cancer surgeries requires further examination. Risk of mortality associated with $\mathrm{SO}$ for all types of patients should be further evaluated (Prado et al. 2008; Batsis et al. 2013). It remains unclear whether the added risk from $\mathrm{SO}$ is the sum of the individual impacts of obesity and sarcopenia or whether these conditions further interact with each other. Finally, current interventions for sarcopenia and $\mathrm{SO}$ have not been robustly verified, due to challenges from risk of adverse reactions when dealing with sarcopenic populations (Cesari $\mathrm{M}$ 2016). Furthermore, these interventions have yet to be tested specifically with regard to cancer surgery patients.

\section{Abbreviations}

ACE: Angiotensin-converting enzyme; ASA: American Society of

Anesthesiologists; ASM: Appendicular skeletal muscle; BIA: Bioelectric impedance analysis; BMI: Body mass index; CT: Computerized tomography;

DXA: Dual x-ray energy absorptiometry; Gl: Gastrointestinal;

HCC: Hepatocellular carcinoma; HUAC: Hounsfield unit average calculation; IADL: Instrumental activities of daily living; ICGR15: Indocyanine green dye retention rate at $15 \mathrm{~min}$; L3mi: Total skeletal muscle cross-sectional area at the level of the third lumbar vertebrae; LSSCEP: Liver surgery-specific

composite endpoint; MELD: Model for End-Stage Liver Disease; MRI: Magnetic resonance imaging; PD: Psoas density; SD: Standard deviation; SFD: Subcutaneous fat distance; SO: Sarcopenic obesity; TBF: Total body fat; TFLV: Total functional liver volume; TPA: Total psoas area; TPV: Total psoas volume; WC: Waist circumference 


\section{Acknowledgements}

Not applicable.

\section{Funding}

Not applicable. There were no sources of funding for this research.

\section{Availability of data and materials}

The authors declare that all data supporting the findings of this study are included in the article.

\section{Authors' contributions}

KM drafted the manuscript. JB, JM, and SH helped draft and critically review the manuscript. All authors read and approved the final version.

\section{Competing interests}

JB has received honoraria from the 2014 Merck/American Geriatrics Society New Investigator Award and is supported by the National Institute On Aging of the National Institutes of Health under Award Number K23AG051681. This content is solely the responsibility of the authors and does not necessarily represent the official views of the National Institutes of Health. SH serves on the advisory board for Emmi Solutions and Mallinckrodt Pharmaceuticals. KM and JM declare no competing interests.

\section{Consent for publication}

Not applicable.

\section{Ethics approval and consent to participate}

Not applicable.

\section{Author details}

${ }^{1}$ Dartmouth College, Hanover, NH, USA. ${ }^{2}$ Dartmouth-Hitchcock Medical Center, Lebanon, NH, USA. ${ }^{3}$ Geisel School of Medicine at Dartmouth, Hanover, NH, USA. ${ }^{4}$ The Dartmouth Institute for Health Policy \& Clinical Practice, Lebanon, NH, USA.

Received: 15 May 2016 Accepted: 26 September 2016 Published online: 26 October 2016

\section{References}

Amini N, Spolverato G, Gupta R, Margonis GA, Kim Y, Wagner D, Rezaee N, Weiss MJ, Wolfgang CL, Makary MM, et al. Impact total psoas volume on short- and long-term outcomes in patients undergoing curative resection for pancreatic adenocarcinoma: a new tool to assess sarcopenia. J Gastrointest Surg. 2015; 19(9):1593-602

Baili P, Micheli A, De Angelis R, Weir HK, Francisci S, Santaquilani M, Hakulinen T, Quaresmas M, Coleman MP. Life tables for world-wide comparison of relative survival for cancer (CONCORD study). Tumori. 2008;94(5):658-68.

Batsis JA, Barre LK, Mackenzie TA, Pratt SI, Lopez-Jimenez F, Bartels SJ. Variation in the prevalence of sarcopenia and sarcopenic obesity in older adults associated with different research definitions: dual-energy X-ray absorptiometry data from the National Health and Nutrition Examination Survey 1999-2004. J Am Geriatr Soc. 2013;61(6):974-80.

Batsis JA, Mackenzie TA, Barre LK, Lopez-Jimenez F, Bartels SJ. Sarcopenia, sarcopenic obesity and mortality in older adults: results from the National Health and Nutrition Examination Survey III. Eur J Clin Nutr. 2014a;68(9):1001-7.

Batsis JA, Sahakyan KR, Rodriguez-Escudero JP, Bartels SJ, Lopez-Jimenez F. Normal weight obesity and functional outcomes in older adults. Eur J Intern Med. 2014b;25(6):517-22.

Batsis JA, Mackenzie TA, Bartels SJ, Sahakyan KR, Somers VK, Lopez-Jimenez F. Diagnostic accuracy of body mass index to identify obesity in older adults: NHANES 1999-2004. Int J Obes (2005). 2016;40(5):761-7.

Bauer JM, Sieber CC. Sarcopenia and frailty: a clinician's controversial point of view. 2008 (0531-5565 (Print)).

Bauer J, Biolo G, Cederholm T, Cesari M, Cruz-Jentoft AJ, Morley JE, Phillips S, Sieber C, Stehle P, Teta D, et al. Evidence-based recommendations for optimal dietary protein intake in older people: a position paper from the PROT-AGE Study Group. J Am Med Dir Assoc. 2013;14(8):542-59.

Baumgartner RN, Koehler KM, Gallagher D, Romero L, Heymsfield SB, Ross RR, Garry PJ, Lindeman RD. Epidemiology of sarcopenia among the elderly in New Mexico. Am J Epidemiol. 1998;147(8):755-63.
Baumgartner RN, Wayne SJ, Waters DL, Janssen I, Gallagher D, Morley JE. Sarcopenic obesity predicts instrumental activities of daily living disability in the elderly. Obes Res. 2004;12(12):1995-2004.

Bonekamp S, Ghosh P, Crawford S, Solga SF, Horska A, Brancati FL, Diehl AM, Smith S, Clark JM. Quantitative comparison and evaluation of software packages for assessment of abdominal adipose tissue distribution by magnetic resonance imaging. Int J Obes. 2008;32(1):100-11.

Buettner S, Wagner D, Kim Y, Margonis GA, Makary MA, Wilson A, Sasaki K, Amini N, Gani F, Pawlik TM. Inclusion of sarcopenia outperforms the modified frailty index in predicting 1-year mortality among 1,326 patients undergoing gastrointestinal surgery for a malignant indication. 2016 (1879-1190 (Electronic)).

Cesari M, Nobili A, Vitale G. Frailty and sarcopenia: from theory to clinical implementation and public health relevance. Eur J Intern Med. 2016. http://dx.doi.org/10.1016/j.ejim.2016.07.021

Chien MY, Huang Ty Fau - Wu Y-T, Wu YT. Prevalence of sarcopenia estimated using a bioelectrical impedance analysis prediction equation in communitydwelling elderly people in Taiwan. 2008 (1532-5415 (Electronic)).

Clavien PA, Barkun J, de Oliveira ML, Vauthey JN, Dindo D, Schulick RD, de Santibanes E, Pekolj J, Slankamenac K, Bassi C, et al. The Clavien-Dindo classification of surgical complications: five-year experience. Ann Surg. 2009;250(2):187-96.

Clegg A, Young J Fau - Iliffe S, lliffe S Fau - Rikkert MO, Rikkert Mo Fau - Rockwood K, Rockwood K. Frailty in elderly people. 2013 (1474-547X (Electronic)).

Cruz-Jentoft AJ, Baeyens JP, Bauer JM, Boirie Y, Cederholm T, Landi F, Martin FC, Michel JP, Rolland Y, Schneider SM, et al. Sarcopenia: European consensus on definition and diagnosis: report of the European Working Group on Sarcopenia in Older People. Age Ageing. 2010;39(4):412-23.

Davison KK, Ford Es Fau - Cogswell ME, Cogswell Me Fau - Dietz WH, Dietz WH. Percentage of body fat and body mass index are associated with mobility limitations in people aged 70 and older from NHANES III. 2002 (0002-8614 (Print)).

Dello SA, Lodewick TM, van Dam RM, Reisinger KW, van den Broek MA, von Meyenfeldt MF, Bemelmans MH, Olde Damink SW, Dejong CH. Sarcopenia negatively affects preoperative total functional liver volume in patients undergoing liver resection. HPB. 2013;15(3):165-9.

Deutz NE, Bauer JM, Barazzoni R, Biolo G, Boirie Y, Bosy-Westphal A, Cederholm T, Cruz-Jentoft A, Krznaric Z, Nair KS, et al. Protein intake and exercise for optimal muscle function with aging: recommendations from the ESPEN Expert Group. Clin Nutr. 2014;33(6):929-36.

Dodson S, Baracos Ve Fau - Jatoi A, Jatoi A Fau - Evans WJ, Evans Wj Fau - Cella D, Cella D Fau - Dalton JT, Dalton Jt Fau - Steiner MS, Steiner MS. Muscle wasting in cancer cachexia: clinical implications, diagnosis, and emerging treatment strategies. 2011 (1545-326X (Electronic)).

Fearon KC, Voss Ac Fau - Hustead DS, Hustead DS. Definition of cancer cachexia: effect of weight loss, reduced food intake, and systemic inflammation on functional status and prognosis. 2006 (0002-9165 (Print)).

Fearon K, Strasser F, Anker SD, Bosaeus I, Bruera E, Fainsinger RL, Jatoi A, Loprinzi C, MacDonald N, Mantovani G, et al. Definition and classification of cancer cachexia: an international consensus. Lancet Oncol. 2011;12(5):489-95.

Fearon KC, Jenkins JT, Carli F, Lassen K. Patient optimization for gastrointestinal cancer surgery. Br J Surg. 2013;100(1):15-27.

Fielding RA, Vellas B Fau - Evans WJ, Evans Wj Fau - Bhasin S, Bhasin S Fau - Morley JE, Morley Je Fau - Newman AB, Newman Ab Fau - Abellan van Kan G, Abellan van Kan G Fau - Andrieu S, Andrieu S Fau - Bauer J, Bauer J Fau - Breuille D, Breuille D Fau - Cederholm T, et al. Sarcopenia: an undiagnosed condition in older adults. Current consensus definition: prevalence, etiology, and consequences. International Working Group on Sarcopenia. 2011 (1538-9375 (Electronic)).

Fouladiun M, Korner U Fau - Bosaeus I, Bosaeus I Fau - Daneryd P, Daneryd P Fau Hyltander A, Hyltander A Fau - Lundholm KG, Lundholm KG. Body composition and time course changes in regional distribution of fat and lean tissue in unselected cancer patients on palliative care - correlations with food intake, metabolism, exercise capacity, and hormones. 2005 (0008-543X (Print)).

Gallagher D, Visser M, De Meersman RE, Sepulveda D, Baumgartner RN, Pierson RN, Harris T, Heymsfield SB. Appendicular skeletal muscle mass: effects of age, gender, and ethnicity. J Appl Physiol. 1997;83(1):229-39.

Gallagher D, Heymsfield SB, Heo M, Jebb SA, Murgatroyd PR, Sakamoto Y. Healthy percentage body fat ranges: an approach for developing guidelines based on body mass index. Am J Clin Nutr. 2000;72(3):694-701.

Harimoto N, Shirabe K, Yamashita YI, Ikegami T, Yoshizumi T, Soejima Y, Ikeda T, Maehara Y, Nishie A, Yamanaka T. Sarcopenia as a predictor of prognosis in patients following hepatectomy for hepatocellular carcinoma. Br J Surg. 2013; 100(11):1523-30, 
Heymsfield SB, Smith R, Aulet M, Bensen B, Lichtman S, Wang J, Pierson Jr RN Appendicular skeletal muscle mass: measurement by dual-photon absorptiometry. Am J Clin Nutr. 1990;52(2):214-8.

Irving BA, Weltman JY, Brock DW, Davis CK, Gaesser GA, Weltman A. NIH ImageJ and Slice-O-Matic computed tomography imaging software to quantify soft tissue. Obesity (Silver Spring, Md). 2007:15(2):370-6.

Joglekar S, Asghar A, Mott SL, Johnson BE, Button AM, Clark E, Mezhir JJ. Sarcopenia is an independent predictor of complications following pancreatectomy for adenocarcinoma. J Surg Oncol. 2015;111(6):771-5.

Kyle UG, Pirlich M Fau - Lochs H, Lochs H Fau - Schuetz T, Schuetz T Fau Pichard C, Pichard C. Increased length of hospital stay in underweight and overweight patients at hospital admission: a controlled population study. 2005 (0261-5614 (Print)).

Lentine KI Fau - Axelrod D, Axelrod D Fau - Abbott KC, Abbott KC. Interpreting body composition in kidney transplantation: weighing candidate selection, prognostication, and interventional strategies to optimize health. 2011 (1555905X (Electronic))

Levolger S, van Vledder MG, Muslem R, Koek M, Niessen WJ, de Man RA, de Bruin RW, ljzermans JN. Sarcopenia impairs survival in patients with potentially curable hepatocellular carcinoma. J Surg Oncol. 2015;112:208-13.

Lieffers JR, Bathe OF, Fassbender K, Winget M, Baracos VE. Sarcopenia is associated with postoperative infection and delayed recovery from colorectal cancer resection surgery. Br J Cancer. 2012;107(6):931-6.

Lodewick TM, van Nijnatten TJ, van Dam RM, van Mierlo K, Dello SA, Neumann UP, Olde Damink SW, Dejong CH. Are sarcopenia, obesity and sarcopenic obesity predictive of outcome in patients with colorectal liver metastases? HPB. 2015;17(5):438-46.

Makary MA, Segev DL, Pronovost PJ, Syin D, Bandeen-Roche K, Patel P, Takenaga R, Devgan L, Holzmueller CG, Tian J, et al. Frailty as a predictor of surgical outcomes in older patients. J Am Coll Surg. 2010;210(6):901-8.

Malafarina V, Uriz-Otano F Fau - Iniesta R, Iniesta R Fau - Gil-Guerrero L, Gil-Guerrero L. Sarcopenia in the elderly: diagnosis, physiopathology and treatment. 2012 (1873-4111 (Electronic)).

McLean RR, Shardell MD, Alley DE, Cawthon PM, Fragala MS, Harris TB, Kenny AM, Peters KW, Ferrucci L, Guralnik JM, et al. Criteria for clinically relevant weakness and low lean mass and their longitudinal association with incident mobility impairment and mortality: the Foundation for the National Institutes of Health (FNIH) Sarcopenia Project. J Gerontol A Biol Sci Med Sci. 2014;69(5):576-83.

Mitsiopoulos N, Baumgartner RN, Heymsfield SB, Lyons W, Gallagher D, Ross R. Cadaver validation of skeletal muscle measurement by magnetic resonance imaging and computerized tomography. J Appl Physiol. 1998;85(1):115-22.

Miyamoto Y, Baba Y, Sakamoto Y, Ohuchi M, Tokunaga R, Kurashige J, Hiyoshi Y Iwagami S, Yoshida N, Yoshida M, et al. Sarcopenia is a negative prognostic factor after curative resection of colorectal cancer. Ann Surg Oncol. 2015; 22(8):2663-8.

Molfino A, Amabile MI, Rossi Fanelli F, Muscaritoli M. Novel therapeutic options for cachexia and sarcopenia. Expert Opin Biol Ther. 2016;16(10):1239-44.

Moon HG, Ju YT, Jeong CY, Jung EJ, Lee YJ, Hong SC, Ha WS, Park ST, Choi SK. Visceral obesity may affect oncologic outcome in patients with colorectal cancer. Ann Surg Oncol. 2008;15(7):1918-22.

Morley JE, von Haehling S, Anker SD. Are we closer to having drugs to treat muscle wasting disease? J Cachex Sarcopenia Muscle. 2014;5(2):83-7.

Mueller N, Murthy S Fau - Tainter CR, Tainter Cr Fau - Lee J, Lee J Fau - Riddell K, Riddell K Fau - Fintelmann FJ, Fintelmann Fj Fau - Grabitz SD, Grabitz Sd Fau - Timm FP, Timm Fp Fau - Levi B, Levi B Fau - Kurth T, Kurth T Fau Eikermann $\mathrm{M}$, et al. Can sarcopenia quantified by ultrasound of the rectus femoris muscle predict adverse outcome of surgical intensive care unit patients as well as frailty? A prospective, observational cohort study. 2015 (1528-1140 (Electronic)).

Pahor M, Guralnik JM, Ambrosius WT, Blair S, Bonds DE, Church TS, Espeland MA, Fielding RA, Gill TM, Groessl EJ, et al. Effect of structured physical activity on prevention of major mobility disability in older adults: the LIFE study randomized clinical trial. JAMA. 2014;311(23):2387-96

Peng PD, van Vledder MG, Tsai S, de Jong MC, Makary M, Ng J, Edil BH, Wolfgang $\mathrm{CL}$, Schulick RD, Choti MA, et al. Sarcopenia negatively impacts short-term outcomes in patients undergoing hepatic resection for colorectal liver metastasis. HPB. 2011;13(7):439-46.

Peng P, Hyder O, Firoozmand A, Kneuertz P, Schulick RD, Huang D, Makary M, Hirose K, Edil B, Choti MA, et al. Impact of sarcopenia on outcomes following resection of pancreatic adenocarcinoma. J Gastrointest Surg. 2012:16(8):1478-86.
Prado CM, Lieffers JR, McCargar L, Reiman T, Sawyer MB, Martin L, Baracos VE. Prevalence and clinical implications of sarcopenic obesity in patients with solid tumours of the respiratory and gastrointestinal tracts: a populationbased study. Lancet Oncol. 2008;9(7):629-35.

Romero-Corral A, Somers VK, Sierra-Johnson J, Thomas RJ, Collazo-Clavell ML, Korinek J, Allison TG, Batsis JA, Sert-Kuniyoshi FH, Lopez-Jimenez F. Accuracy of body mass index in diagnosing obesity in the adult general population. Int J Obes. 2008;32(6):959-66.

Roubenoff R. Sarcopenic obesity: the confluence of two epidemics. (1071-7323 (Print)).

Sabel MS, Lee J, Cai S, Englesbe MJ, Holcombe S, Wang S. Sarcopenia as a prognostic factor among patients with stage III melanoma. Ann Surg Oncol. 2011;18(13):3579-85.

Sabel MS, Terjimanian M, Conlon AS, Griffith KA, Morris AM, Mulholland MW, Englesbe MJ, Holcombe S, Wang SC. Analytic morphometric assessment of patients undergoing colectomy for colon cancer. J Surg Oncol. 2013:108(3):169-75.

Shen W, Punyanitya M, Wang Z, Gallagher D, St-Onge MP, Albu J, Heymsfield SB, Heshka S. Total body skeletal muscle and adipose tissue volumes: estimation from a single abdominal cross-sectional image. J Appl Physiol. 2004;97(6):2333-8.

Singh $M$, Stewart $R$, White $H$. Importance of frailty in patients with cardiovascular disease. 2014 (1522-9645 (Electronic)).

Studenski SA, Peters KW, Alley DE, Cawthon PM, McLean RR, Harris TB, Ferrucci L, Guralnik JM, Fragala MS, Kenny AM, et al. The FNIH sarcopenia project: rationale, study description, conference recommendations, and final estimates. J Gerontol A Biol Sci Med Sci. 2014;69(5):547-58.

Teh SH, Christein J, Donohue J, Que F, Kendrick M, Farnell M, Cha S, Kamath P, Kim R, Nagorney DM. Hepatic resection of hepatocellular carcinoma in patients with cirrhosis: Model of End-Stage Liver Disease (MELD) score predicts perioperative mortality. J Gastrointest Surg. 2005;9(9):1207-15. discussion 1215

Tsai S. Importance of lean body mass in the oncologic patient. Nutr Clin Pract. 2012;27(5):593-8

van Gijn W, Gooiker GA, Wouters MW, Post PN, Tollenaar RA, van de Velde CJ. Volume and outcome in colorectal cancer surgery. Eur J Surg Oncol. 2010;36 Suppl 1:S55-63.

van Vledder MG, Levolger S, Ayez N, Verhoef C, Tran TC, ljzermans JN. Body composition and outcome in patients undergoing resection of colorectal liver metastases. Br J Surg. 2012;99(4):550-7.

Villareal DT, Banks M Fau - Siener C, Siener C Fau - Sinacore DR, Sinacore Dr Fau Klein S, Klein S. Physical frailty and body composition in obese elderly men and women. 2004 (1071-7323 (Print)).

Villareal DT, Chode S, Parimi N, Sinacore DR, Hilton T, Armamento-Villareal R, Napoli N, Qualls C, Shah K. Weight loss, exercise, or both and physical function in obese older adults. N Engl J Med. 2011;364(13):1218-29.

Visser M, Kritchevsky SB, Goodpaster BH, Newman AB, Nevitt M, Stamm E, Harris TB. Leg muscle mass and composition in relation to lower extremity performance in men and women aged 70 to 79 : the health, aging and body composition study. J Am Geriatr Soc. 2002;50(5):897-904.

Voron T, Tselikas L, Pietrasz D, Pigneur F, Laurent A, Compagnon P, Salloum C, Luciani A, Azoulay D. Sarcopenia impacts on short- and long-term results of hepatectomy for hepatocellular carcinoma. Ann Surg. 2015;261(6):1173-83.

Yoshizumi T, Nakamura T, Yamane M, Islam AH, Menju M, Yamasaki K, Arai T, Kotani K, Funahashi T, Yamashita S, et al. Abdominal fat: standardized technique for measurement at CT. Radiology. 1999;211(1):283-6.

Zamboni M, Mazzali G, Fantin F, Rossi A, Di Francesco V. Sarcopenic obesity: a new category of obesity in the elderly. Nutr Metab Cardiovasc Dis. 2008; 18(5):388-95.

\section{Submit your next manuscript to BioMed Central and we will help you at every step:}

- We accept pre-submission inquiries

- Our selector tool helps you to find the most relevant journal

- We provide round the clock customer support

- Convenient online submission

- Thorough peer review

- Inclusion in PubMed and all major indexing services

- Maximum visibility for your research

Submit your manuscript at www.biomedcentral.com/submit 